\title{
Success Factors and Benefits of Social Franchising as a Form of Entrepreneurship
}

\begin{abstract}
Marta Ziótkowska*
This paper is a conceptual study on the essence of social franchising as a business model and form of entrepreneurship. Social franchising has been utilised by the social sector in a variety of ways, yet franchising as a form of social entrepreneurship context is a new area of research. Despite the increasing popularity of social franchising to scale and replicate social enterprises, there has been little research on this topic. There is a need for a better understanding of the basics of the phenomenon and clarification of its fundamental meaning. The essence of social franchising as an organisational form with huge potential has been presented. The paper examines social franchising by showing the model and analyses of its benefits and success factors in comparison to commercial franchising. Moreover, the study provides basic characteristics and knowledge for future in-depth research with regard to this topic.
\end{abstract}

Keywords: social franchise, non-profit, third sector, entrepreneurship, social enterprise.

Submitted: 12.08.2016 | Accepted: 09.10.2016

\section{Czynniki sukcesu i korzyści franczyzy społecznej jako formy przedsiębiorczości}

Artykut to konceptualne studium na temat istoty franczyzy spotecznej jako modelu biznesu i formy przedsiębiorczości. Franczyza społeczna jest wykorzystywana przez trzeci sektor różnorodnie, lecz franczyza $w$ kontekście formy spotecznej przedsiębiorczości jest nowym obszarem badawczym. Pomimo wzrostu popularności franczyzy spotecznej by skalować i replikować przedsiębiorstwa spoteczne niewiele jest badań na ten temat. Istnieje potrzeba lepszego zrozumienia podstaw $i$ wyjaśnienia fundamentalnego znaczenia tego zjawiska. Zaprezentowano $w$ artykule istote franczyzy społecznej jako forme organizacyjna o dużym potencjale. W artykule zbadano franczyze spoteczna, prezentują model oraz analizę korzyści i czynników sukcesu $w$ porównaniu z franczyza komercyjnq. Ponadto opracowanie dostarcza podstawowej charakterystyki $i$ wiedzy do dalszych pogtębionych badań w niniejszej tematyce.

Słowa kluczowe: franczyza społeczna, non-profit, trzeci sektor, przedsiębiorczość, przedsiębiorstwo społeczne.

Nadesłany: 12.08.2016 | Zaakceptowany do druku: 09.10.2016

JEL: L26

\footnotetext{
Marta Ziółkowska, PhD - Warsaw School of Economics, Institute of Management, Unit of Corporate Management.

Mailing address: Warsaw School of Economics, Institute of Management, Unit of Corporate Management; Al. Niepodległości 162; 02-554 Warsaw; e-mail: mziokow@sgh.waw.pl.
} 


\section{Introduction}

Nowadays, there seems to be an increased tendency to apply practical, innovative and supportable approaches to addressing the current most pressing problems, while using the existing resources most effectively and simultaneously. A new type of enterprise has emerged and has been diffused throughout the world. A term that has become associated with this development is social entrepreneurship. Social entrepreneurs - in a similar manner to entrepreneurs in the business sector - act as change agents for society. Social business models ${ }^{1}$ are enabling organisations to tap into new sources of funding and organise governance and accountability structures in a way that resonates with the mission of the organisation. Social enterprises operate in the market to achieve social goals. Nevertheless, the majority of decision-makers from the so-called third sector were, for a long time, reluctant to use business tools (Ahlert, 2008, p. 11). There was a clear distinction between forprofit and non-profit sectors. The increased acceptance of the importance of social entrepreneurship can be interpreted as a paradigm shift. The process also includes the application of commercial tools to increase the impact of projects and to make them more lasting (Ahlert, 2008, p. 11).

Franchising that can be used to solve social problems is social franchising, which involves the application of business-format franchising (commercial franchising) to achieve social benefits. Nevertheless, there is little knowledge about social franchising within the ecosystem of social enterprises. The goal of this paper is to deepen the knowledge of social franchising and conceptualise the main definitions and characteristics through an overview of the benefits and success factors of this organisational form from a commercial franchise perspective. This paper addresses the gap in the current literature and research by presenting the advantages, success factors and problems of using social franchise to satisfy social needs in the economy. The paper is conceptual in nature and is based on an overview of literature available on the subject, as well as on the analysis of accessible data. It examines franchising in the non-profit sector by discussing the benefits of and limitations to social franchise usage as well as success factors through the traditional versus social franchising analysis.

The author would like to focus strictly on social franchising as an organisational form. Given the comprehensive literature on traditional franchising, the author limited the definitions and references to commercial franchising in this paper apart from the identification of similarities and differences of both forms - commercial and social.

\section{Essence of Social Franchising as a Form of Social Entrepreneurship}

While franchising has been around for a rather long time, social franchising is a relatively new phenomenon. Traditional ${ }^{2}$ franchising is a system of doing business which allows the franchisor to transfer the system of know-how, intellectual property in return for royalties (Alon, 2005, 2010). It is known as business format franchising and product franchising and has a long history worldwide, which dates back to the 19th century. During the 1940s and 1950s, franchising was a business model innovation for that time Franchising has a welldocumented track record in the developed world as a very effective organisational form. The business-in-a-box model reduces risk and makes replication relatively simple. It is assumed that franchising accounts for 10-25\% of GDP among OECD member nations (Mukherjee, 2008). Franchising has been an effective strategy for replicating successful concepts for over 80 years in the commercial world, but it has as yet not been so popular in the non-profit sector. The history of franchising usage in the nonprofit sector dates back to the early 1990s (Sadowska, 2009).

However, to conduct research it is necessary to understand the fundamentals of the practice of franchising in the social enterprise context. Social franchising is primarily a method for transferring knowledge from one established social enterprise to another that wants to achieve the same social and financial goals. Social franchising is a method in the process of social innovation dissemination and a type of replication of social enterprise possible 
to develop in today's economy. The idea of social franchising is to use a successfully developed business system method to support social needs.

Given that social franchising is a relatively new area of research, the term is used in many different ways and there is no obvious definition. There is a diversity of perceptions of what is meant by the term social franchising but no consensus on the final definition (Crawford-Spencer, 2015). There is a need for a better understanding of the various forms of the phenomenon and clarification of its fundamental meaning. The prior research work that took into consideration social franchising within the healthcare and educational context in the developing world mostly focused on health aspects (Alur, 2011; Bishai et al.; Bishai et al., 2008, 2012; Ngo et al., 2010). Tracey and Jarvis (2007) were the first to attempt to analyse social franchising. Their research concluded that agency and resource scarcity theories are insufficient to conceptualise this new format.

Basically, social franchising is an adaptation of commercial franchising in which the developer of a successful social concept (franchisor) enables others (franchisees) to replicate the model using a proven system and a brand name to achieve social benefit. Social franchising can be defined as a system of contractual relationships that uses the structure of a commercial franchise to achieve social goals (Tracey and Jarvis, 2007). Social franchise emerges with the objective to make a social impact by tackling pressuring social issues such as unemployment, social exclusion of groups, poverty, social cohesion, protection of the environment, health, and education.

Nevertheless, social franchising is the use of a commercial franchising approach to replicate and share proven organisational models for greater social impact. The use of franchising to solve social problems is based on the essential feature of that kind of business - replication. Social franchise facilitates the scaling up of the business to fulfil social needs. Schuhen (2004, pp. 156157) suggests a more functional definition: 'Social Franchising is the non-profit form of vertical or horizontal cooperation with the aim of replicating social programmes and services as well as governing and linking social organizations'. Consequently, social franchising must also be considered a form of cooperation between equal partners. As such, social franchising is also a matter of cultivating partnership, joining forces and benefitting from cooperative organisations. More specifically, social franchising can be understood as contract-based cooperation of decentralised entrepreneurial units with a central support unit, uniform quality standards and supported by a common philosophy (Braun and Lotter, 2004, p. 9).

The interest in social franchising is gaining momentum around the world, as it may be structured in many different forms, including sole proprietors, for-profit and non-profit firms, non-governmental organisations, youth groups, community organisations, and more. It is worth mentioning that a social franchise operates in both the non-profit and the commercial sector. A common feature differentiating social franchising from other forms is the aim to satisfy social needs and use franchising as a scalable form of venture. Moreover, a social franchise promotes entrepreneurship and helps to instil entrepreneurial behaviours among excluded groups of people (disadvantaged people). Social franchising is a method that allows the replication of proven success whilst retaining local ownership (see Figure 1).

A social franchise has the following key attributes. Firstly, there is a legally binding franchise agreement between the social franchisor and independent social franchisees under a common brand. Secondly, the franchisor replicates the proven business model and shares its knowledge and resources by providing training and support for partners in the operations manual. It covers all the knowhow, procedures and techniques for how to operate a franchise unit as well as issues connected with quality and performance standards. Moreover, a core thing in franchise cooperation is that training is provided in the start-up phase and continued during the business relation. The social franchise agreement is defined by a quality assurance system, including performance monitoring. The franchisor is obliged to ensure financial feasibility and donor support (if applicable) for the franchise system. Through replicating 


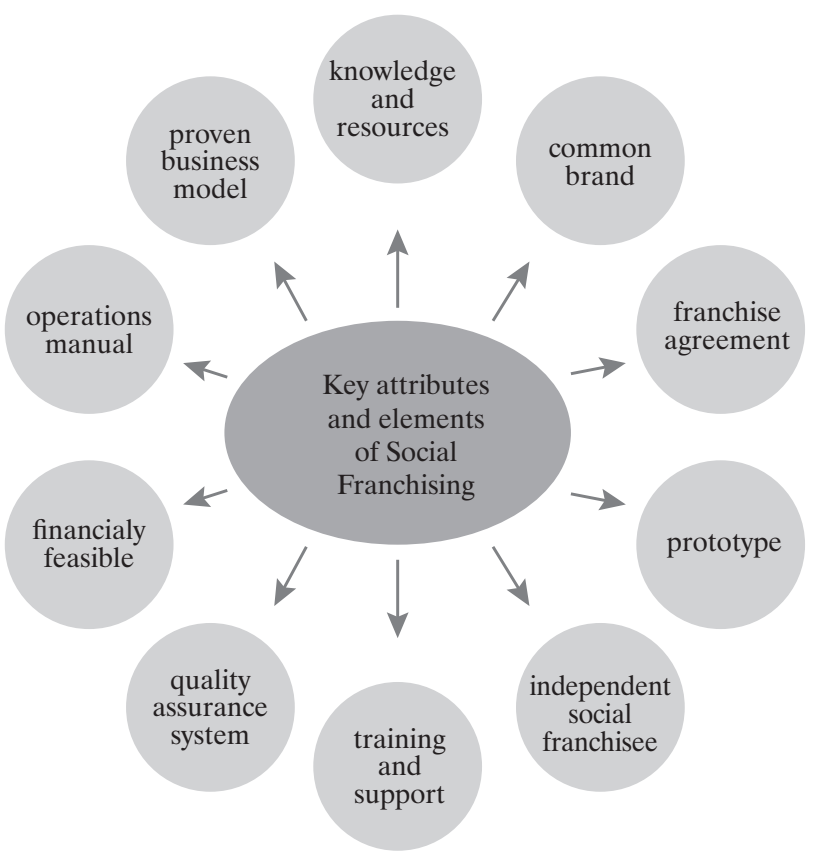

Source: own work based on M. Ziótkowska, Franczyza nowoczesny model rozwoju biznesu, CeDeWu, Warszawa 2010.

proven concepts, franchising leverages existing resources, instead of creating a new service at a high cost. Because the decentralised units are based on a tested prototype, the initial start-up risks are reduced. Furthermore, franchisors provide their franchisees with a whole concept of how to run the non-profit project. This allows franchisees to focus on their core competences, thereby implementing, rather than administering and developing, the system.

Social franchising enables independent entrepreneurs to become franchisees to deliver services to end-customers (see Figure 2). The model of social enterprise creates infrastructure and empowers businesspersons (or disadvantaged persons) to satisfy social needs when there is a lack of distribution of social services. The social franchise represents different ways of doing business but the common goal is the same - satisfaction of social needs. However, the most well-known examples of social franchise are: Komosie's De Kringwinkel (Flanders) recycling shops and refurbishment business, CAP supermarkets (Germany) and LeMat hotels (Italy) (European Social Franchise Network). Moreover, there are a few well established social franchise ventures in the UK: Green Works charity recycling furniture (Sharpen, 2006), The School for Social Entrepreneurs (SSE) and FareShare (FareShare) charity supporting communities to relieve food poverty by tackling both food poverty and food waste. Social franchising is growing in Poland with representation in this sector. There is a successful example of the social franchise development model - Barka (Sadowska, 2009). The aim of Barka is to support disadvantaged people. Other cases are: K-Lumet (production of kindling) and Klubo-kawiarnia 'Spółdzielnia' (supporting social events, trainings and education for disadvantaged people) (Franczyza społeczna). Moreover, there exist some international social franchises operating in Poland such as: Aflatoun (education) (Bloom, 2012), Specialisterne (employs people with autism) (Specialisterne). 
Figure 2. Model of social franchise creation

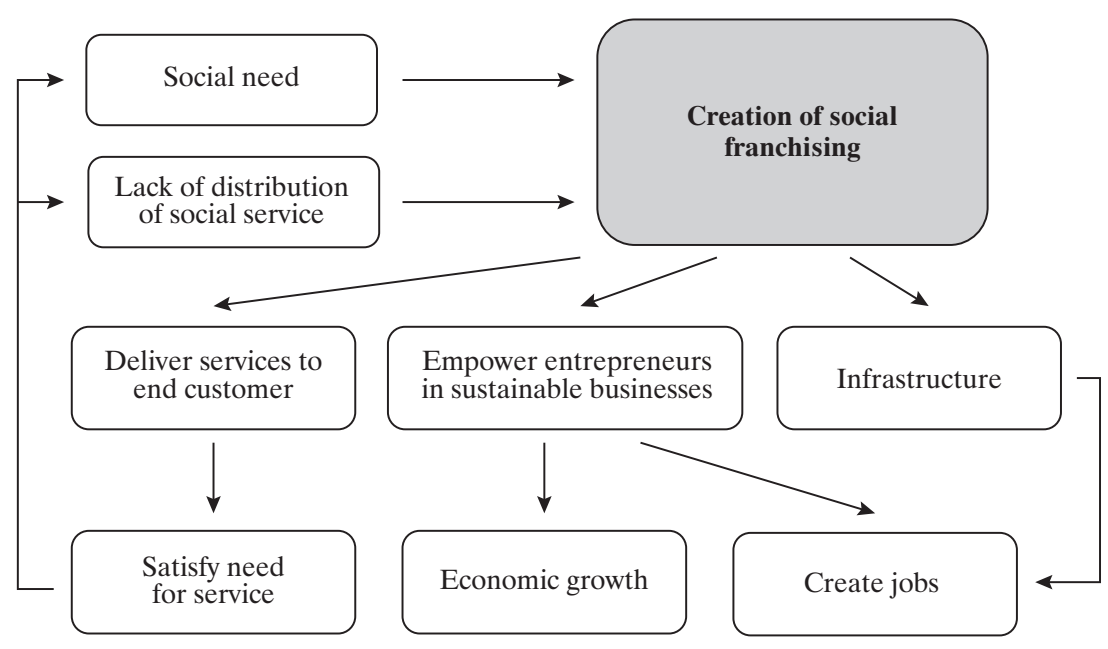

Source: own work based on A. Du Toit, Social Franchising as an Organizational Format - An Overview. In: I. Alon (ed.) Social Franchising, Palgrave Macmillan 2014.

\section{Characteristics \\ of Social Franchise Formats and the Differences from Commercial Franchising}

Potential social franchise formats range from commercial franchises with intended social effects to non-profit replication systems with franchising elements. Three formats can be identified in principle. The first one is a commercially organised franchise system for achieving social benefits. The sole difference from commercial franchising is the focus of the system as a whole on social benefits and the absence of the primary goal of generating profit for private individuals. The second is a subsidised franchise system that makes services available at a lower cost than commercial solutions. This may include profit-making entrepreneurs at the franchisee level. The final one is a nonprofit replication system which includes the core elements of franchising, but without the classical fee and profit elements.

Most of the core elements of social franchising are similar to commercial franchising. The common issues in social and commercial franchises are: a proven model, easily learned and scalable (duplicable), high levels of upfront development and ongoing involvement and obligations, with which high costs are associated. Moreover, an important feature is a common, shared identity, which means that there is a risk for the franchisor. Both business models are based on a legal agreement, and the licences granted under the agreement are used in particular territories and set out the fee payments.

Nevertheless, there are some differences between the franchise systems in the commercial and in the non-profit sector (Smith, 2002). First of all, there is a different objective. The main objective in the third sector is not to maximise profit, but rather to maximise social impact. This means that the franchisor might be less commercial in recruiting and managing its franchisees. Furthermore, franchising disciplines may be harder to implement and to control. The second issue is a different target group. In social franchising, the 'client base' is different. A non-profit organisation on the whole serves beneficiaries rather than customers.

There is an additional player in a social franchise who guarantees financial support. This is the case during the start-up phase, but also in order to remain sustainable. This adds a further player to the equation - the donor. The donor most likely has its own policies and programmes. This might lead to a conflict of interest for the franchisor 
and the franchisees who have to take the preferences of the donors into account.

A crucial problem applies to fees. Franchisees in a social franchise system might not be able to pay franchise fees, as they cannot always expect a return on investment. Therefore, the franchisor should be willing to accept the payment of reduced fees or alternatives to monetary compensation. The 'payment' could, for example, entail the allocation of important data or quality information that the franchisor can use for the development of its project (Schuhen, 2004).

Moreover, there are also some differences in franchisee selection between commercial and social ventures. Commercial franchisees can quite often be individuals rather than organisations. This is less likely in social franchising, given the type of products and services being replicated. In social franchising, franchisees must share all of the objectives of the franchisor, including not only the financial ones but also the social objectives that flow from the organisation's mission. This will often form a key part of the selection criteria for franchisees in social franchising. Nevertheless, social franchisors may be more likely to put emphasis on the values and culture that underpin their approach, and make this a key part of the selection criteria and training of franchisees. The social franchisor should provide detailed support, training and advice for the franchisees. A pilot project that is developed by the franchisor is replicated by a number of franchisees subject to defined guidelines.

A significant difference from traditional franchising is the objective to serve customers in order to satisfy their various needs, whereas, for commercial franchises, the importance to maintain customer loyalty is paramount. As with social enterprises, it is not only measuring the financial bottom line that is important in commercial franchising, but also measuring the social impact. Social franchises should ensure that an evaluation framework for measuring social impact is established before replication, as it will form part of the systems utilised by franchisees. This emphasis on shared evaluation also helps ensure that the focus remains on achieving social impact (the original reason for replication) and there is a system for continuous improvement.
The approach to profits differentiate the two presented formats. A social business venture generates profits, but rather than return those profits to shareholders, like commercial ventures, it reinvests those profits to further the social venture and provide the resulting social benefits. A distinguishing characteristic of a social venture versus a commercial venture is the primacy of its objective to solve social problems and bring social benefits. A social venture may generate profits, but that is not its focus. Profits are rather a possible means to achieve sustainability in providing social benefits. The problems addressed by social ventures cover the range of social issues, including poverty, inequality, education, the environment, and economic development. The context in which social ventures operate is very complex as they are trying to bring about solutions where markets or governments may have failed or actually impede solutions (Osberg et al., 2007).

\section{Success Factors of Social Franchising}

Social franchising has a number of success factors (see Figure 3). Due to the limited length of this paper, the author focused on analysing the success factors of social franchising at the macro level and from the franchisor perspective. First of all, a proven and replicable social business model is a success factor. The starting point of social franchise development is a wellestablished business concept when the pilot phase is finished. Success is measured both by success in reaching social goals and by the ability to demonstrate profitability. That it is replicable means that it has been possible to describe and standardise the most critical processes in the enterprise so that someone else can follow them.

Secondly, social value is an added value, with a focus on service delivery. A social enterprise must, in the first instance, deliver quality services or products to its customers. Whatever the activity, a social enterprise must be able to compete with any other company in its sector. The fact that a social enterprise has social goals creates added value for customers.

Careful selection of franchisees is an extremely important issue in social franchising. Regardless of how good the 
Figure 3. Success factors of social franchising

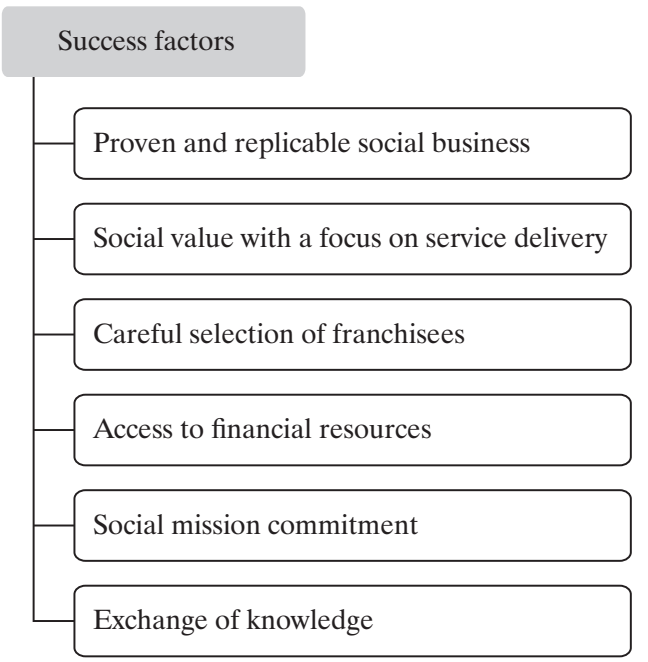

Source: own work based on diffused sources.

franchise is, wrong entrepreneurs can cause the business to fail. A franchisor exerts the greatest influence on the future outcome of the business during the choice of franchisees. For this reason, franchisors must have a clear picture of the type of franchisees they want, as well as know how to guarantee that the franchisees are entrepreneurs capable of taking action.

Since replication leads to increased cooperation and more contracting in the non-profit sector, it is essential to have workable franchisees. The most ideal franchisees are a type of 'entrepreneur-lite': they must have the drive and skills to lead and own their own business, but cannot be so entrepreneurial and opportunistic that they are not able to follow the franchise system they have signed up to. Research shows that non-profit projects organised by franchise systems grow twice as fast as other systems (Wei-Skillern and Anderson, 2003, p. 12).

The development of social franchise requires access to financial resources. The franchisor must have financial resources in order to develop the concept. A crucial factor is to remain true to the social mission of the social enterprise. It is easy to lose sight of social goals when an enterprise expands. As demands from employees, financiers and other stakeholders increase, so many other aspects become important for survival. Franchisors are required to create a platform to exchange knowledge within the system. To be successful in franchising, franchisors need to facilitate the exchange of experience between the franchisees to use the synergy effect.

To sum up, it is worth mentioning that generally the success factors indicated that social franchises are similar to commercial franchises. Those elements are largely extrapolated from franchising in the commercial sector, as social franchising is still in the incipient stage with limited examples to draw conclusions.

\section{Benefits and Problems of Social Franchising}

Social franchising therefore brings a considerable number of benefits (see Figure 4). Benefits and problems in this part concern the social franchise as a system (whole organisation) and franchisors as creators of this business concept.

First and foremost, the potential benefits for the social franchisor are the rapid expansion of social impact and concept. The benefits of franchising, including expansion with reduced capital and the replication of a proven business system, are attractive to practitioners in the non-profit 
sector. Practitioners in this market refer to social enterprises as 'profit-making, not profit-taking' (Du Toit, 2014, p. 12). All the characteristics of social franchising and social enterprise refer to the achievement of social goals. However, the pursuit of social goals does not negate the importance of running these businesses on commercial principles to ensure their continuity and longevity. Most social franchise businesses need to make enough profit to achieve sustainability and social franchises need to operate on commercial principles, but not for commercial goals.

Secondly, social franchisors need less managerial and other staff compared to a wholly owned expansion system. They can benefit from economies of scale and local knowledge. All the above mentioned issues are exactly the same as for the traditional franchisor operating in the commercial market. Some authors (Asemota and Chahine, 2016) list other common benefits for social and traditional franchisors such as fewer financial sources required for expansion compared to a wholly owned company. This presents a misunderstanding of the social franchising idea. It is worth mentioning that in social franchising most franchisors are responsible for providing funds needed for system expansion. They can use their own resources, government support, donors' assistance or other forms offering money for social ventures. The source of funding in social franchising is different to that in traditional franchising. The general idea in social franchising is that financial resources come from the franchisor to franchisees. This is opposite to traditional franchising where franchise fees are paid by franchisees to the franchisor. Moreover, social franchisees' benefits and risks are relatively similar to those of franchisees operating in the commercial market.

An important issue is that social franchisors make it easier and safer for social entrepreneurs (franchisees) to set up enterprises, providing them with a proven business model and access to trade-specific support. The core concern in the long-term commitment is that social franchisors are a market-driven trade-specific business support structure that will only survive if it effectively supports the establishment of successful social franchisees. Thus the social franchisor will only work with people who think that they can succeed over the long term.

Another benefit is the creation of entrepreneurship at the local level. Social franchising is built on the creation of successful locally controlled enterprises. Compared to a multi-national global company, they contribute more to the local economy and ensure that jobs are not outsourced to other areas or countries.

Despite the many advantages that social franchising offers as a replication model, various problems may nonetheless prevail. First of all, there is a risk of changing the initial mission. Adapting it to local peculiarities might alter the original mission created by the franchisor. Additionally, the franchisees' goals might differ from those presented by the franchisor, as well as those of other franchisees. Franchisees do not have to provide start-up capital, because the initial investments are usually made by the franchisor or a donor. Consequently, because franchisees fear less capital loss, they might behave opportunistically and their motivation to adhere to the system might be lower.

Figure 4. Benefits and problems of the social franchising operation

\begin{tabular}{|l|}
\hline \multicolumn{1}{|c|}{ Benefits } \\
\hline - market innovators \\
- meeting local needs \\
- easy and safe social start-up \\
- long-term commitment \\
built on creation of successful local \\
enterprise
\end{tabular}

Source: own study based on diffused sources.

\begin{tabular}{|l|}
\hline Limitatons \\
\hline - risk of changing the initial mission \\
- negative reputation \\
- stanitoring and evaluation difficulties \\
- competition and fundraising \\
\hline
\end{tabular}

\section{Source: own study based on diffused sources.}


Furthermore, the risk of negative reputation can be another drawback of social franchising. Operating under the same name, the various units in a social franchise system are perceived as one organisation. Consequently, the reputation of one affiliate has an impact on the organisation as a whole. Franchisees might present themselves in a way which is inconsistent with the central unit. Therefore, the franchisor has to ensure an appropriate level of control over the franchisees.

Consequently, another difficulty can be found in the standardisation of the system, which is an important element. Standardisation is a core element of any social franchise system. However, because the essential knowledge and skills are often tacit, the standardisation of non-profit projects can be difficult. Also, the success of an initiative is often dependent on specific geographic or cultural peculiarities. Excessive standardisation might therefore lead to inflexibility, making it more difficult to adapt the project at other locations. It is thus important to find the right balance between standardisation and flexibility.

In comparison, the potential limitations are exactly the same for social and traditional franchisors. First of all, there is the risk of insufficient alignment of the mission and organisational culture to effectively replicate results and the risk of inadequate selection of franchisees. Nevertheless, social franchisees have to consider some risks consistent with operating under a franchise agreement. From the point of view of the social franchisee, potential risks are the same as in a traditional franchise agreement and cover amongst others risks in the area of financial, organisational and cultural issues. Financial risk is connected with sharing a part of percentage revenues and profits with the franchisor where applicable. Secondly, there is the risk of inconsistency of the franchisor's standardised procedures with existing internal systems and organisational culture; hence the risk that the franchise system will not prove to be as effective in the local context.

\section{Conclusions}

The main theoretical contribution of the paper was the analysis of success factors and benefits of social franchising. The author offered the characteristics of social franchising derived from investigating the differences between social and traditional franchising and provided the main descriptions of the social franchise characteristics. It is worth mentioning that franchising is a successful strategy of systematic replication in the commercial sector and entails an effective concept that has been tried and tested, being implemented by largely independent franchisees at other locations within a common framework and supported by a contractual agreement. There is the potential of adapting franchising to the social environment.

The complexity of success factors impacting the outcome of social franchising has already been clearly highlighted. Success factors are variable and depend on the exact nature of the business and social impact model. However, the key factors for success are cross-cutting and include the timing of the decision to franchise, selecting the right franchisee, drawing up an appropriate franchise agreement, and continuous evaluation of the franchise network (Berelowitz, 2012). Benefits and success factors of social franchising would determine the future development of this form. Moreover, the study has shown that there are some similarities of typical franchise elements such as an agreement on longer-term cooperation between the franchisor and the franchisee based on a legal contract and the interplay between control and entrepreneurial freedom in the partners' relationships.

Considering the benefits and success factors of the social franchise, there are several reasons why a franchising approach to replication might be attractive to social enterprises. For example, it creates social impact in line with the mission, but without expanding an organisation in a traditionally hierarchical way that creates distance from the frontline. The social franchise shares existing knowledge, making it quicker and easier to start up, and allows for local ownership, flexibility and tailoring to context and circumstance. Franchising shares successful models in a way that combines social and financial goals and ensures social impact and financial sustainability.

Nevertheless, when transposed into social entrepreneurship, it is different from 
commercial franchising. Moreover, the most important modification to traditional franchises concerns the ultimate goal of social franchising. Social franchises strive to achieve the highest possible social profit, not the commercial one. The motivation of social franchisees is strongly connected with commitment to the social mission, not to financial profits.

To summarise, social franchising could appear as a promising solution to tackle both the problems of unemployment, social exclusion of groups, and poverty as well as the problems of unsatisfied social needs that the public sector and NGOs are facing, and to provide the necessary tools to the formation, financial sustainability, and growth of social enterprises. Social franchising could also appear as a solution to the structural and behavioural problems that inter-organisational alliances and business format franchising are facing.

This study provides foundational findings for future research in the nascent area of social franchising. Research is needed to better understand the possibilities for social franchising to give an opportunity to solve social problems and encourage disadvantaged people to be active in the field of entrepreneurship, analyse which forms of social franchises as a form of entrepreneurship are implemented in the market as well as to understand the risks and benefits of social franchising for participants in different contexts. The further stage of the research should involve comparing the benefits and limitations as well as the success factors for social and commercial franchises, with a division into the franchise system, franchisor and franchisee. The next step is an exploratory study of growth possibilities for social franchising and its possible usage in governmental policy to create an environment to counteract social problems.

Concerning practical implications, the outlined benefits and success factors can encourage entrepreneurs together with non-entrepreneurs to expand social ventures using franchise relations. Social franchising can open up business options to disadvantaged people representing various groups of people from former prisoners to single parents. Exploiting franchise for satisfying social needs can resolve some social problems in the society. For this reason, social franchising should be taken into consideration by policy makers and country governments as they are seeking systematic solutions to achieve social objectives.

\section{Endnotes}

1 Osterwalder et al. (2005) consider the Business Model as the blueprint of how a company does business.

2 Also known as commercial franchising. Commercial franchising and traditional franchising are used alternatively in the present paper.

\section{References}

Ahlert, D. (2008). Social franchising. A way of Systematic Replication to Increase Social Impact. Berlin: Bundesverband Deutscher Stiftungen.

Alur, S. and Schoormans, J.P. (2011). Sustainable rural healthcare and social franchisee selection - An India study. Journal of Medical Marketing, 11(3), 230-236, http://dx.doi. org/10.1177/1745790411411264.

Alon, I. (2005). Service franchising: A global perspective. New York: Springer.

Alon, I. (2010). Franchising globally. New York: Palgrave Macmillan.

Asemota, J. and Chahine, T. (2016). Social franchising as an option for scale. Voluntas, 1-29, http: $\mathrm{dx}$. doi.org/10.1007/s11266-016-9763-7.

Bartilsson, S. (2012). Social franchising - Obtaining higher returns from investments for jobs in social enterprises. Sweden: Coompanion Goteborgsregionen.

Bishai, D., Mirchandani, G., Pariyo, G., Burnham, G. and Black, R. (2008). The cost of quality improvements due to integrated management of childhood illness (IMCI) in Uganda. Health Economics, 17, 5-19.

Bishai, D.M. and Champion, C. (2012). The economics of social franchising for health in low- and middle-income countries. In: D. Peters, H. Lucas, B. Kanjilal and G. Bloom (eds), Transforming health markets in Asia and Africa: Improving quality and access for the poor (pp. 162-179), http:dx.doi. org/10.4324/9780203102060.

Bloom, P.N. (2012). Scaling your social venture: Becoming an impact entrepreneur. Macmillan.

Braun, J. and Lotter, D. (2004). Franchising im Stiftungswesen. Stiftung\&Sponsoring, 6.

Berelowitz, D. (2012). Social franchising: Innovation and the power of old ideas. Published by the Clore Social leadership programme, the international centre for social franchising and social enterprise UK Retrieved from: http://www.the-icsf.org/wp-content/ 
uploads/2016/05/Social-Franchising-Innovationand-the-Power-of-Old-Ideas.pdf (28.08.2016).

Crawford-Spencer, E. (2015). Deriving meaning for social franchising from commercial franchising and social enterprise. Journal of Marketing Channels, Jul-Sep, 22(3), 163-174, http://dx.doi.org/10.1080/1 046669X.2015.1071585.

Du Toit, A. (2014). Social franchising as organizational format - An overview. In: I. Alon (ed.), Social franchising (pp. 8-32). Palgrave Macmillan, http://dx.doi.org/10.1057/9781137455840.0005.

European Social Franchise Network. http:// www.socialfranchising.coop/case-studies/page/1 (28.08.2016).

Fareshare. http://www.fareshare.org.uk (28.08.2016).

Franczyza Społeczna. http://www.franczyzaspoleczna. $\mathrm{pl} / \mathrm{pl} /$ franczyzy-spoleczne-w-polsce (28.08.2016).

Gopalakrishnan, K., Prata, N., Montagu, D., Mitchell, B. and Walsh, J. (2000). NGOs providing low cost, high quality family planning and reproductive health services. Case study: Janani - India. Bay Area International Group Monograph Series, 1(3-4).

Martin, R.L. and Osberg, S. (2007). Social entrepreneurship: The case for definition. Stanford Social Innovation Review, Spring, 28-39.

Mukherjee, S. (2008). WORTH and social franchising: Initial research and analysis. Retrieved from: https://docs.google.com/presentation/d/1DGmuU EDuk0YeRSMargiin0mVI19HtKaN0jG6pv-E_ks/ edit\#slide=id.i0 (25.06.2016).

Osterwalder, A., Pigneur, Y. and Tucci C.L. (2005) Clarifying business models: Origins, present, and future of the concept. Communications of the Association for Information Systems, 16.

Ngo, A.D., Alden, D.L., Pham, V. and Phan, H. (2010). The impact of social franchising on the use of reproductive health and family planning services at public commune health stations in Vietnam. BMC Health Services Research, 10, http://dx.doi. org/10.1186/1472-6963-10-54.
Richardson, M., Berelowitz, D. (2012). Social franchising. Research for Big Society Capital by The International Centre for Social Franchising, September.

Sadowska, B. (ed.). (2009). Nowy poczatek spoteczna gospodarka rynkowa: 1989-2009 [The new beginning. The social market economy from 1989 to 2009]. Poznań: Fundacja Pomocy Wzajemnej BARKA [Barka - Foundation for Mutual Aid].

Schuhen, A. (2004). Franchising: ein Modell für den Nonprofit-Sektor? In: H. Kötz, P. Rawert, K. Schmidt and W.R. Walz (eds.), Non Profit Law Yearbook 2003, 151-166. Köln: Carl Heymanns Verlag. Sharpen, C. (2006). Social enterprise under the microscope: comparing and contrasting Green-Works and ReBoot. Social Enterprise Journal, 2(1), 101-113, http://dx.doi. org/10.1108/17508610680000716.

Smith, E. (2002). Social franchising reproductive health services. Can it work? A review of the experience. Marie Stopes International Working Papers, 5, February.

Specialisterne. http://specialisterne.com (28.08.2016). SSE The School of Social Entrepreneurs. https:// www.the-sse.org (28.08.2016).

Tracey, P. and Jarvis, O. (2007). Towards a theory of social venture franchising. Journal of Entrepreneurship: Theory and Practice, 31(5), 667-685, http:// dx.doi.org/10.1111/j.1540-6520.2007.00194.x.

Volery, T. and Hackl, V. (2010). The promise of social franchising as a model to achieve social goals. In: A. Fayolle and H. Matley (eds.), Handbook of Research on Social Entrepreneurship (pp. 157-181). Cheltenham UK, Northampton MA USA: Edward Elgar Publishing.

Wei-Skillern, J. and Anderson, B. (2003). Non-profit Geographic Expansion: Branches, Affiliates, or Both? Social Enterprise Series no. 27, Harvard Business School Working Paper Series No. 4-011.

Ziółkowska, M. (2015). Franczyza - nowoczesny model rozwoju biznesu [Franchise - modern model of business development]. Warszawa: CeDeWu. 